\title{
スクロール圧縮機作動室内の油が性能に及ぼす影響*
}

\author{
椎 林 正 夫*1, 東 條 健 司*1 \\ 池川正人*1, 村山朗*2
}

\section{Influence of Circulated Refrigerating Oil in Compression Chamber on Performance for Scroll Compressors}

\author{
Masao SHIIBAYASHI, Kenji TOJO, \\ Masato IKEGAWA, and Akira MURAYAMA
}

\begin{abstract}
In order to the predict performance of scroll compressors, it is important to estimate both mechanical losses and gas compression power. The mechanical losses are mainly due to the stirring forces of the refrigerating oil and frictional forces between moving parts. It is necessary to understand the influence of the oil on the compressor for improving the accuracy of performance prediction. In this study, sealing effects and cooling effects of the refrigerating oil, which have not yet been studied sufficiently, are discussed. As a result, the effects of the refrigerating oil on the compressor performance and cooling characteristic are clarified.
\end{abstract}

Key Words : Fluid Machine, Scroll Compressor, Performance, Refrigerating Oil, Oil Content, Seal, Cooling

1. 緒言

スクロール压縮機の性能を予測するためには,ガス 圧縮動力と機械損失動力の両者を見積もる必要があ る. 前者のガス圧縮動力の計算については，東條らに よる計算機シミュレーションによる方法がある(1). 一 方後者の機械損失動力には，摩擦損失のほかバランス ウェイトが油の中をふれまわるときに生ずるかくはん 損失などがあり，これらの計算法については石井ら ${ }^{(2)}$ と著者ら ${ }^{(3)}$ にって提示されている．図1にスクロー ル圧縮機の性能に及ほす影響因子の概要を示す，圧縮 機内部を循環する油の機能として，（1）スクロールラ ップ間のシール作用，（2）圧縮機の各しゅう動部の潤 滑，(3)作動ガスの圧縮熱を吸収する冷却作用などの 良い作用をする反面，上記したかくはん損失が生じる といった悪い作用がある．性能面での油の影響を明確 化することは，圧縮機の性能予測の精度向上のために

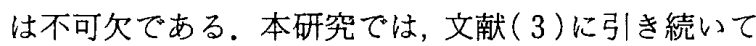
これまで明確になされていなかった油のシール作用と 作動ガスへの冷却作用および圧縮性能に及ほす影響

* 昭和 63 年 11 月 11 日 北陸信越支部北陸地方講演会におい て講演, 原稿受付 昭和 63 年 5 月 31 日.

*1 正員，(株) 日立製作所機械研究所 ( $\mathbf{3} 300$ 土浦市神立町 502 ).

*2（怢）日立製作所清水工場（画424 清水市村松 390）。
を，計算と実験とで検討した。

$$
\text { 主な記号の説明 }
$$

$C_{p 0}:$ 油の比熱

$C_{p r}$ : 冷媒ガスの定圧比熱

$G_{0 j}$ : 背圧室油量（質量流量）

$G_{0 s}$ : 吸入側油量（質量流量）

$G_{r}$ : 冷媒流量（質量流量）

$L_{0}$ : 圧縮機動力

$L_{0 p}$ : 循環油加圧動力

$N ：$ 回転速度

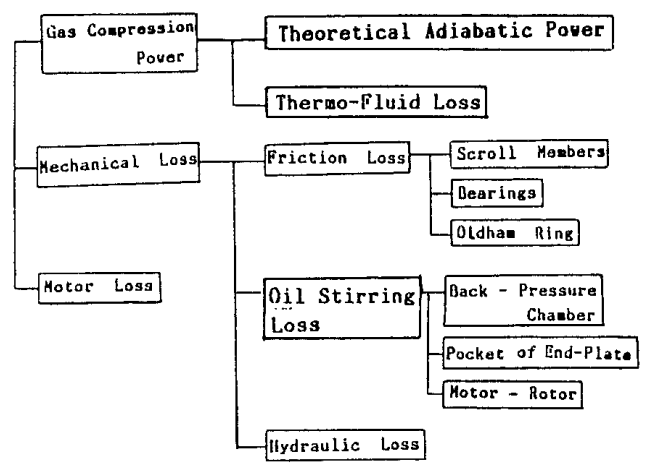

図 1 スクロール压縮機の性能影響因子 


$\begin{aligned} & Q_{c h}: \text { チャンバ放熱量 } \\ & Q_{h}: \text { 圧縮機全熱入力 } \\ & Q_{0}: \text { 油の得た熱量 } \\ & Q_{r}: \text { 冷媒ガスの得た熱量 } \\ & P: \text { 圧力 } \\ & T: \text { ガス温度 } \\ & V: \text { 容積 } \\ & V_{t h}: \text { 行程容積 } \\ & \xi, \xi_{0}: \text { 油含有率 } \\ & \rho_{0}: \text { 油の密度 } \\ & \text { 添字ほか } \\ & d: \text { 吐出し } \\ & i: \text { 作動室 } \\ & s: \text { 吸入 } \\ & *: \text { 基準となる値 }\end{aligned}$

\section{2. 供試圧縮機と油の流れ}

$2 \cdot 1$ 供試圧縮機 図 2 と図 3 は本研究で供試し た実験用スクロール圧縮機の全体構造を示す. 図 2 の 圧縮機はチャンバ内が高温・高圧の零囲気にある縦形 の密閉形圧縮機である．上部に固定スクロールと旋回 スクロールからなる圧縮要素部を,下部には電動機を 配している．旋回スクロールの鏡板とフレームで囲ま れた背圧室は, 鏡板に設けられた背圧孔を介して圧縮 室と連通しており，この室内の圧力は吸入圧力と吐出 し圧力との中間的圧力となる。このため軸受部にはク ランク軸下端の吐出し圧力と背圧室の圧力との差圧を 利用して給油される.一方図 3 の圧縮機は横形で, 圧

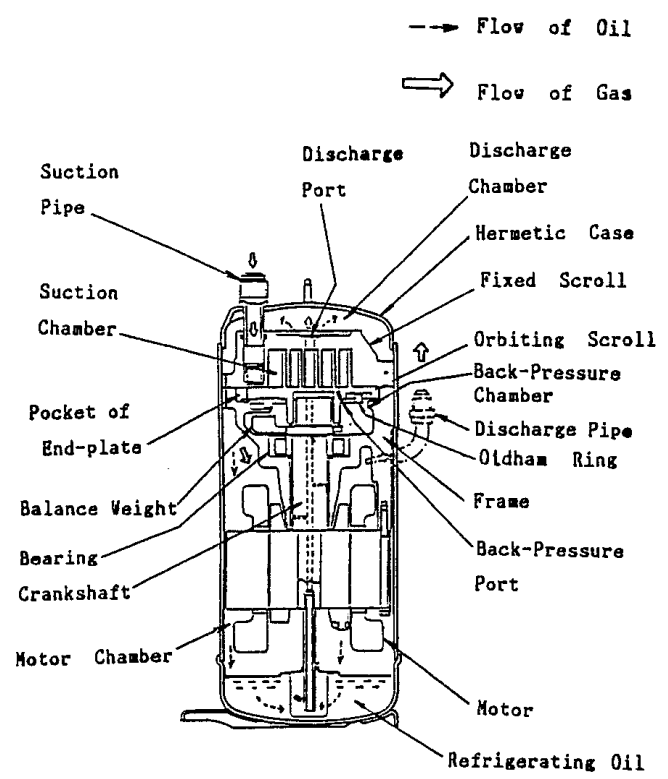

図 2 密閉形スクロール圧縮機の全体啭造
縮要素部の固定スクロールはラップと反対の面が大気 に露出しており，旋回スクロールの駆動はオルダムリ ングおよびクランク軸を介して別設置の電動機にて行 う開放形圧縮機である。両供試機は，電動機の定格出 カが $2.2 \mathrm{~kW}$ と $3.0 \mathrm{~kW}$ の空気調和機用スクロール圧 縮機で主な仕様を表 1 に示す。

$2 \cdot 2$ 圧縮機内部のガスと油の流れ 図 4 に密閉 形圧縮機における内部のガスと油の流れの概要を示 す. 冷媒ガスは吸入側油 $G_{0 s}$ とともに吸入管より吸入 室を経て直接スクロール圧縮要素部に吸入され，スク ロール部の圧縮作用により徐々に圧力と温度が高めら れて固定スクロール上方の昍出し室に至る。なお軸受 部から背圧室に流入した油 $G_{0 j}$ は，ここから背圧孔を 介して, 作動室内の圧力が背圧室の圧力より低いとき に作動室に移動し，冷媒ガスおよび吸入側油と混合さ れる.このように密閉形圧縮機の場合には，スクロー ルの作動室に流入した吸入側油と背圧室油は一緒にな って冷媒ガスとともに加圧される．吐出し室の冷媒ガ スと油 $\left(G_{0 s}+G_{0 j}\right)$ は下部の電動機室に至り，ここでガ

表 1 供試圧縮機の主な仕様

\begin{tabular}{|l|c|c|c|}
\hline Type & & Hermetic & Open \\
\hline Displacement Volume & $\mathrm{cm}^{3}$ & 62.4 & 45.0 \\
\hline Built-in Volume Ratio & & 2.7 & 2.8 \\
\hline Motor Noninal Output & $\mathrm{k} . \mathrm{V}$ & 3.0 & 2.2 \\
\hline
\end{tabular}

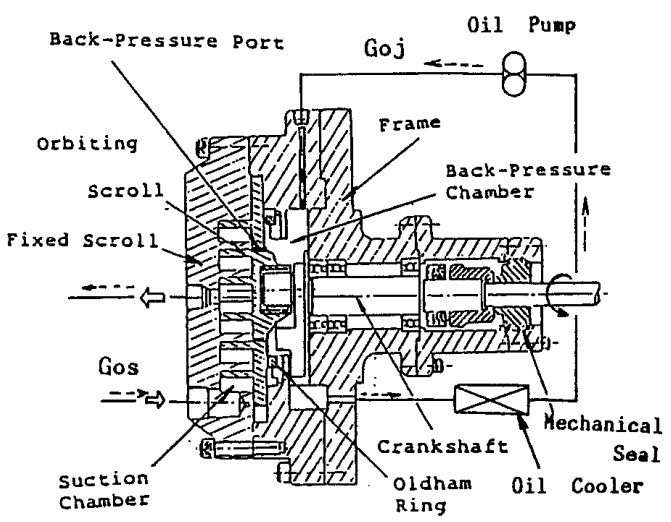

図 3 開放形スクロール圧縮機の全体構造

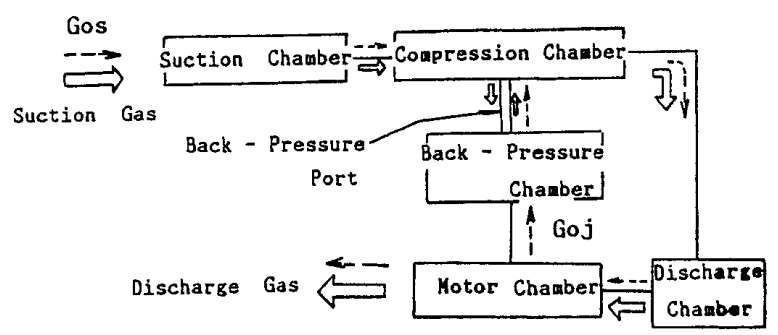

図 4 圧縮機内部のガスと油の流れ 
ス中に含まれた油の大部分を分離して吐出し管を通つ て外部に導かれる。電動機室で分離された油はチャン バ下部に落下し，再び軸受部に供給される。一方開放 形圧縮機においては，図 3 に示すように，作動室内を 循環する吸入側油の流れと，軸受部などの背圧室の内 部を潤滑するため外部の給油ポンプにて油を循環させ る背圧室油の流れの二つの給油経路を構成している. したがって，この場合には，吸入側油のみが冷媒ガス とともに加圧される。なおこの油の加圧に要する動力 を以後「循環油加圧動力」と称する.

\section{$2 \cdot 3$ 油の冷却性能と循環油加圧動力}

（1）油の冷却性能吸入側油は吐出しガス温度 $T_{d}$ の低減に効果があり, 油による $T_{d}$ 低減の作用を 計算で求める. 図 5 に密閉形スクロール圧縮機の簡易 的に求めた熱汉支モデルを示す，吸入ガス温度 $T_{s}$ を 基準にして熱計算をすすめる，圧縮機への全熱入力 $Q_{h}$ と冷媒がスと吸入側油が圧縮機内部で受ける熱量 $Q_{r}, Q_{0}$ とは, チャンバ放熱量 $Q_{c h}$ を考慮して次の関係 がある、なおこの場合吸入側油の温度は，吸入ガス温 度 $T_{s}$ と同じ温度となっている。

$$
\begin{aligned}
& Q_{h}=Q_{r}+Q_{0}+Q_{c h} \ldots \ldots \\
& Q_{h}=L_{0} \quad \ldots \ldots \ldots \ldots \ldots \ldots \ldots \\
& Q_{r}=G_{r} \cdot C_{p r} \cdot\left(T_{d}-T_{s}\right) \\
& Q_{0}=G_{0 s} \cdot C_{p 0} \cdot\left(T_{d}-T_{s}\right)
\end{aligned}
$$

次に吸入側油量 $G_{0 s}$ が変わっても冷媒流量および压 縮機動力とチャンバ放熱量が変わらないと仮定する と, 上式から

$$
G_{r} \cdot C_{p r} \cdot\left(T_{d}-T_{s}\right)+G_{0 s} \cdot C_{p 0} \cdot\left(T_{d}-T_{s}\right)
$$$$
=\text { Const. }
$$

となる. 式 (5)から吸入側油量に対する昍出しガス温 度の変化割合 $d T_{d} / d G_{0 s}$ は,

$$
\frac{d T_{d}}{d G_{0 s}}=-\frac{C_{p 0}\left(T_{d}-T_{s}\right)}{G_{r} \cdot C_{p r}+G_{0 s} \cdot C_{p 0}}
$$

で与えられる。したがって吐出しがス温度の変化分 $\Delta T_{d}$ は次式で示される。

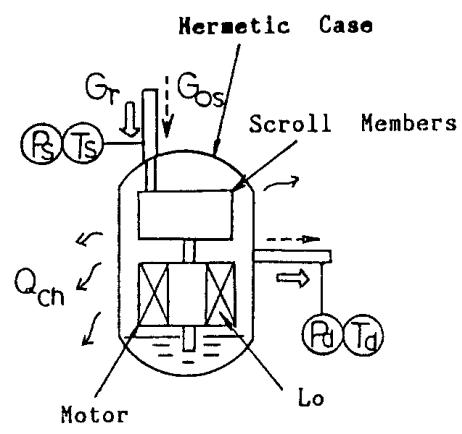

図 5 密閉形スクロール圧縮機の熱収支モデル

$$
\Delta T_{d}=-\frac{C_{p 0}\left(T_{d}-T_{s}\right)}{G_{r} \cdot C_{p r}+G_{0 s} \cdot C_{p 0}} \cdot \Delta G_{0 s}
$$

ここで $\Delta T_{d}$ と $\Delta G_{0 s}$ はある基準となる值をもとにし て表すと次式のとおりとなる。

$$
\begin{aligned}
& \Delta T_{d}=T_{d}-T_{d *} \cdots \\
& \Delta G_{0 s}=G_{0 s}-G_{0 s *}
\end{aligned}
$$

吸入側油量 $G_{0 s}, G_{0 s *}$ を次式で定義した油含有率 $\xi$, $\xi_{*}$ で表す。

$$
\begin{aligned}
& \xi=\frac{G_{0 s}}{G_{r}+G_{0 s}} \cdots \\
& \xi_{*}=\frac{G_{0 s *}}{G_{r *}+G_{0 s *}}
\end{aligned}
$$

上式から, 油含有率の変化に伴う吐出しガス温度の変 化分 $\Delta T_{d}$ を求めると, 式 $(7)$ は次式で置き換えられ る.

$$
\Delta T_{d}=-\frac{C_{p 0}\left(T_{d *}-T_{s}\right)}{C_{p r}+C_{p 0}\left(\frac{\xi_{*}}{1-\xi_{*}}\right)} \cdot\left\{\frac{\xi}{1-\xi}-\frac{\xi_{*}}{1-\xi_{*}}\right\}
$$

（2）循環油加圧動力 スクロールの作動室内を 循環する油は，冷媒ガスとともに加圧され，この循環 油加圧動力 $L_{0 p}$ は次式で与えられる ${ }^{(4)}$. 密閉形圧縮機 の場合は

$$
L_{0 p}=\frac{1}{\rho_{0}}\left\{G_{0 s} \cdot\left(P_{d}-P_{s}\right)+G_{0 j}\left(P_{d}-P_{b}\right)\right\}
$$

また開放形圧縮機の場合は次のとおりである.

$$
L_{0 p}=\frac{G_{0 s}}{\rho_{0}} \cdot\left(P_{d}-P_{s}\right)
$$

\section{3. 実 験 方 法}

図 6 に実験装置の概要を示す，圧縮機は作動ガスを 冷媒 R 22 としたガスサイクル装置に接続し, 性能測 定は所定の実験条件でサイクルが安定するまで運転し た状態で計測した。ガス流量はルーツ式ガス流量計に て, 圧縮機動力は三相電力計にて計測した.また，圧縮 機のチャンバ下部と油分離器から導いた油を, 油冷却 器と油量計を介して吸入配管側へ戻す油配管を設け， 配管途中の止め弁の開度により吸入側油量 $G_{0 s}$ の調 整を行った。吸入配管を介してスクロールの作動室に 注入される油が圧縮機内部の圧力にどのような影響を 及ぼすか調べるため, 指圧線図を計測しさらに吸入室 と鏡板外周ポケットの圧力を小形圧力変換器を用いて 計測した．指圧線図の計測法については文献 ( 5 ) とお おむね同一の方法なので説明を省略する，圧縮機各部 の具体的な圧力の計測位置を図 7 に示す.なお図 7 中 （）で示した記号は，各測定位置における圧力の值を 示す.また，吸入ガス温度 $T_{s}$ と吐出しガス温度 $T_{d}$ を 
計測するため, 銅-コンスタンタン熱電対を冷媒ガス の吸入口および吐出し口に近い吸入配管と吐出し配管 の内部に取付けた，表 2 と表 3 に今回の実験条件と供 試した冷凍機油の主な物性值を示す。ここで作動室に 注入される油量を次式で与えられる油含有率 $\xi_{0}$ とし て定義する，密閉形圧縮機の場合，

$$
\xi_{0}=\frac{G_{0 s}+G_{0 j}}{G_{r}+G_{0 s}+G_{0 j}}
$$

一方開放形圧縮機の場合には

$$
\xi_{0}=\frac{G_{0 s}}{G_{r}+G_{0 s}}
$$

となる。なお式(15)中の背圧室油量 $G_{0 j}$ の值は, 計 算 $^{(6)}$ と予備実験で得られた值を用いた。

\section{4. 実験 結果と検 討}

$4 \cdot 1$ 油のシール作用と冷却性能 図 8 に開放形 圧縮機における油含有率 $\xi_{0}$ と指圧線図の関係を示す. また図 $9 に \xi_{0}$ と吐出しガス温度 $T_{d}$ および背圧室圧 力 $P_{b}$ との関係を示す. 図 8,9 ともに, 回転速度 $N$, 圧 力条件 $P_{d}, P_{s}$, 吸入ガス温度 $T_{s}$ を一定にし, 油含有率 多のみを変更したものである．これらの $T_{d}$ と $P_{b}$ の 值は，基準とする $\xi_{0 *}$ のときの $T_{d *}, P_{b *}$ をとにし てそれらとの差 $T_{d}-T_{d *}$ あるいは比 $\left(P_{b} / P_{b *}\right)$ により

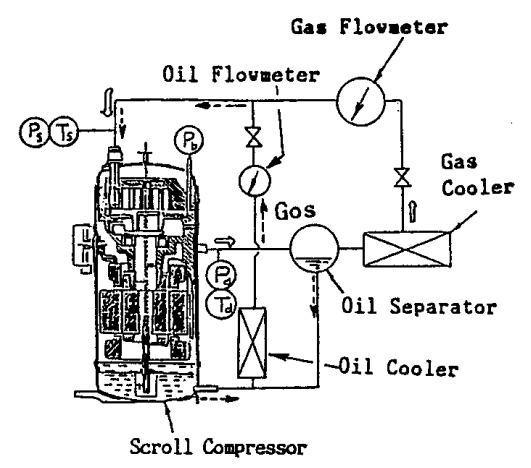

図 6 実験装置

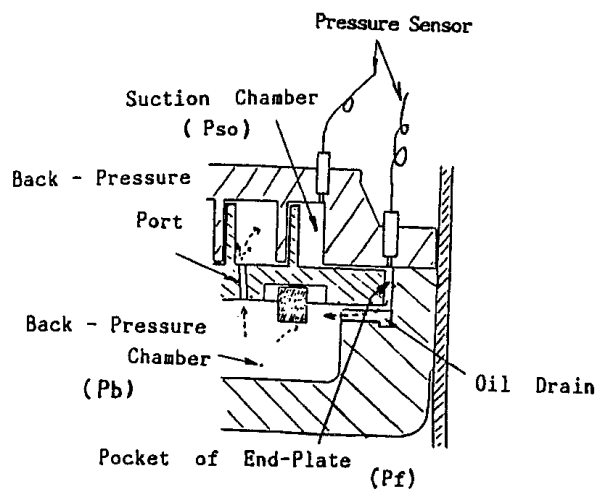

図 7 圧縮機内部の圧力計測の位置
表示した，なお基準とした $\xi_{0 *}$ は，後述の図 10 で示し た圧縮機軸動力 $L_{0}$ が最も小さくなったときの $\xi_{0}$ を 選定している。この基準となる油含有率 $\xi_{0 *}$ は，開放 形圧縮機では $\xi_{0 *}=6 \%$, 密閉形圧縮機では $\xi_{0 *}=7.5$ \%の値である. 図 8 から， $\xi_{0}=2 \%$ から $\xi_{0}=4 \%$ と油を ふやすと指圧線図は断熱圧縮線に近づき，油によるシ 一ル効果が増大していることがわかる，压縮開始付近 では $\xi_{0}$ の差による圧力曲線の変化はほとんど見られ ないが, 圧縮行程の中盤以降から $\xi_{0}$ の差によるシー ル作用の違いが顕著に表れている。これはスクロール ラップ間の漏れ特性と関連している(1). $\xi_{0}$ の差による シール作用の変化は, 図 9 の背圧室圧力の変化にも表 れている. 図 8 において, 指圧線図が断熱圧縮線より 上にふくらみ，そのふくらみ具合いが大きくなると， 作動室とつながっている背圧室の圧力もそれに応じて 上昇する．また図 9 から，和が $5 \%$ より増大した領域 では $P_{b}$ がほとんど変化していないことがわかる、こ のことは，この領域では $\xi_{0}$ を大くしても油のシー ル効果が， $\xi_{0}=5 \%$ 場合と同程度であることを示唆

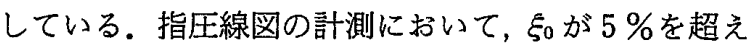
た領域では圧力曲線に大きな変化のないことを確認し ている。

一方，油による冷却性能に関しては，図 9 から $\xi_{0}$ が 大きくなるにしたがい $T_{d}$ 值は漸減し，油による冷却 効果が表れていることがわかる，この $T_{d}$ 変化の実験 結果は計算結果とおおむね一致している，計算結果で は $\xi_{0}$ が $1 \%$ 増加すると， $T_{d}$ は約 $1.6^{\circ} \mathrm{C}$ の比率で低下

表 2 実験条件

\begin{tabular}{|l|c|c|}
\hline & Unit & Condition \\
\hline Gas & & $\mathrm{R}-22$ \\
\hline Pressure Ratio & & 3.5 \\
\hline Suction Pressure & $\mathrm{MPa}$ & 0.6 \\
\hline Discharge Pressure & $\mathrm{MPa}$ & 2.1 \\
\hline $\begin{array}{c}\text { Suction Gas } \\
\text { Temperature }\end{array}$ & ${ }^{\circ} \mathrm{C}$ & 20.0 \\
\hline 0il Ratio of Flov & $\%$ & $2.0 \sim 25.0$ \\
\hline $\begin{array}{c}\text { Temperature of } 0 \mathrm{il} \\
\text { Supply }\end{array}$ & ${ }^{\circ} \mathrm{C}$ & 20.0 \\
\hline Speed & $\mathrm{s}^{-1}$ & 57.8 \\
\hline
\end{tabular}

表 3 冷凍機油の物性值

\begin{tabular}{|l|c|c|}
\hline & Unit & Physical Properties \\
\hline Density & $\mathrm{g} / \mathrm{cu}^{3}$ & 0.94 \\
\hline Viscosity & $\mathrm{a}^{2} / \mathrm{s}$ & $55.0 \times 10^{-6}\left(40^{\circ} \mathrm{C}\right)$ \\
& 2 \\
$\mathrm{u}^{2} / \mathrm{s}$ & $6.3 \times 10^{-6}\left(100^{\circ} \mathrm{C}\right)$ \\
\hline $\begin{array}{c}\text { Specific } \\
\text { Heat }\end{array}$ & $\mathrm{kJ} / \mathrm{kc} / \mathrm{k}$ & 2.01 \\
\hline
\end{tabular}


する.なお $\xi_{0}$ が $5 \%$ より小い領域と $\xi_{0}$ が $15 \%$ より 大きい領域では, 実験値の $T_{d}$ が計算值の $T_{d}$ より高 く表れている.これは後述する圧縮機動力の増加によ る影響と考えられる。

$4 \cdot 2$ 圧縮性能油含有率 $\xi_{0}$ が圧縮性能に及ぼす 影響の実験結果を, 循環油加圧動力 $L_{0 p}$ の計算結果と 併せて図 10 に示す. 縦軸の各性能值は, 基準となる油 含有率 $\xi_{0 *}$ のときの体積効率 $\eta_{v *}$, 圧縮機動力 $L_{0 *}$ を もとにして, それらの比 $\eta_{v} / \eta_{v *}, L_{0} / L_{0 *}, L_{0 p} / L_{0 *}$ で表 している，なお基準とした $\xi_{0 *}$ は前述したとおりであ る.また図 11 に吸入配管を介して作動室に油を注入し たときの吸入室圧力 $p_{s 0}$ と鏡板外周ポケット圧力 $p_{f}$ の圧縮機 1 回転あたりの圧力変化を示す. 図 10 から $\xi_{0}$ が $5 \%$ より小さい領域では，自が低下すると体積 効率 $\eta_{v}$ と圧縮機動力 $L_{0}$ が大きく変化し, 圧縮性能が 低下していることがわかる．この原因は油のシール作 用の低下に伴うガス漏れの増加と再圧縮動力の増加の

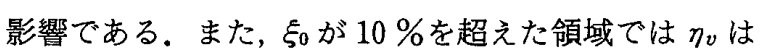

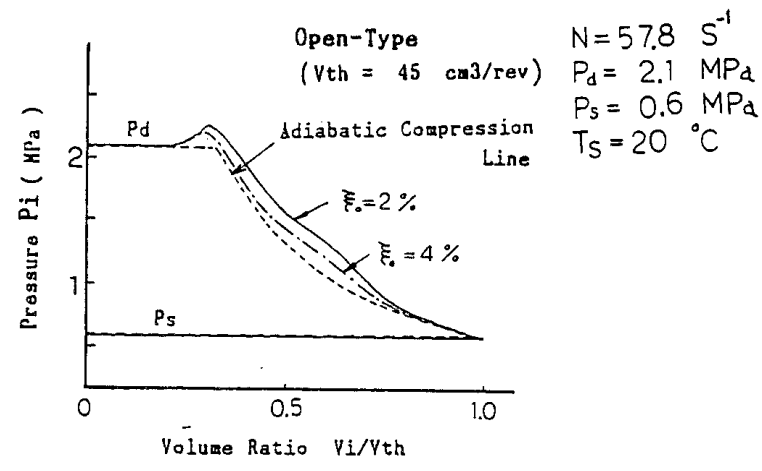

図 8 油含有率と指圧線図との関係

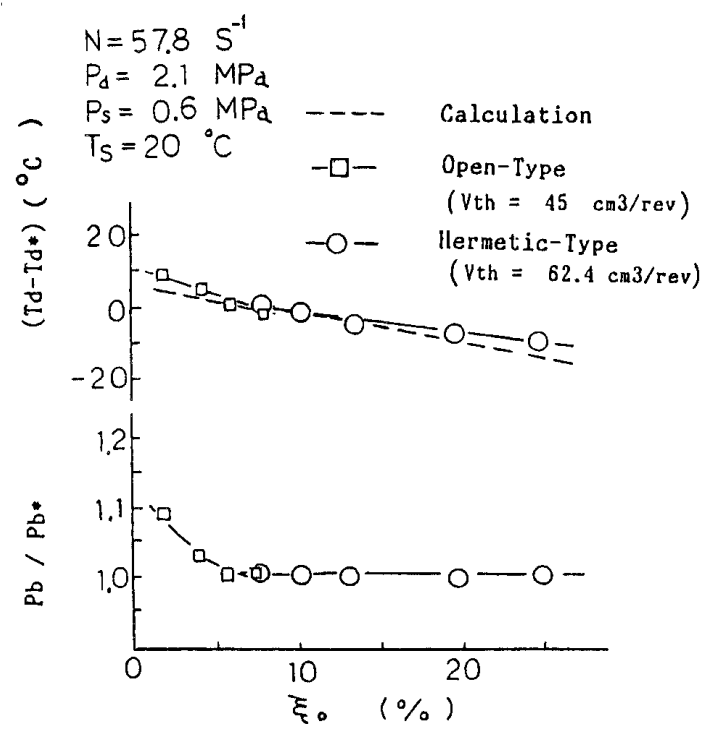

図 9 油含有率と冷却性能との関係
変わらず, $L_{0}$ が $\xi_{0} に$ 対してゆるやかに増加してい る.この動力増加は, 図 11 の圧力変動が若干増大した 様子から同えるように, 吸入室および背圧室内での油 かくはん損失が増加したためと考えられる(3).なお $L_{0 p}$ の計算值は, 圧縮機動力 $L_{0}$ に対してきん少であ り， $L_{0 p}$ は大きな影響を及ぽさないと判断できる.以 上のことから圧縮性能と冷却性能の観点から，列は 5 \%から $10 \%$ 範囲が適正であることがわかった.なお 図 11 から，吸入配管を介して作動室に油を注入して やると, 鏡板外周ポケットの圧力変動がわずかながら 増加していることがわかる。この部分の圧力変動の大 きさと,この部分にとどまっている油の量とは相関の あることが知られており ${ }^{(3)}$ ，上記した $P_{f}$ の圧力挙動 から作動室内の油は，背圧孔を介して背圧室側に，ひ いては鏡板外周ポケットへ移動していると推察され る.

\section{5. 結言}

スクロール圧縮機の作動室内を循環する油が, 冷媒 ガスの冷却と圧縮性能に及ぼす影響を計算と実験にて 検討を行い，以下の結論を得た。

（1）作動室を循環する油の量は, 冷却と圧縮性能 の観点から適正值がある.この值は油量と冷媒ガス量 との比率で定義した油含有率 $\xi_{0}$ で表示すると，おお
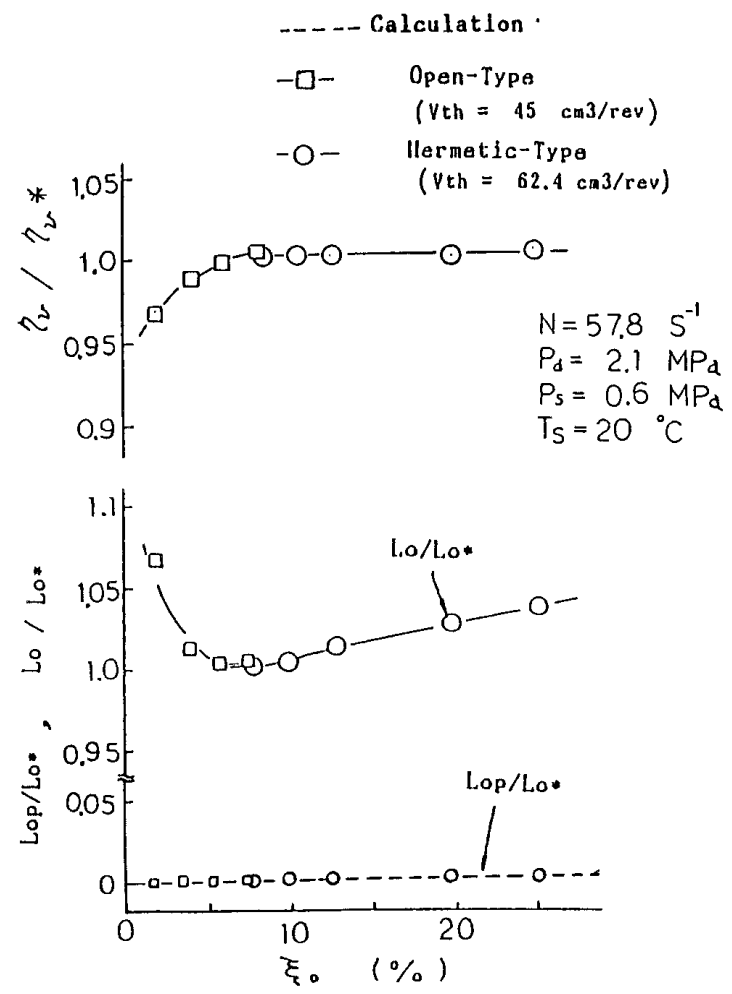

図 10 油含有率と圧縮性能との関係 


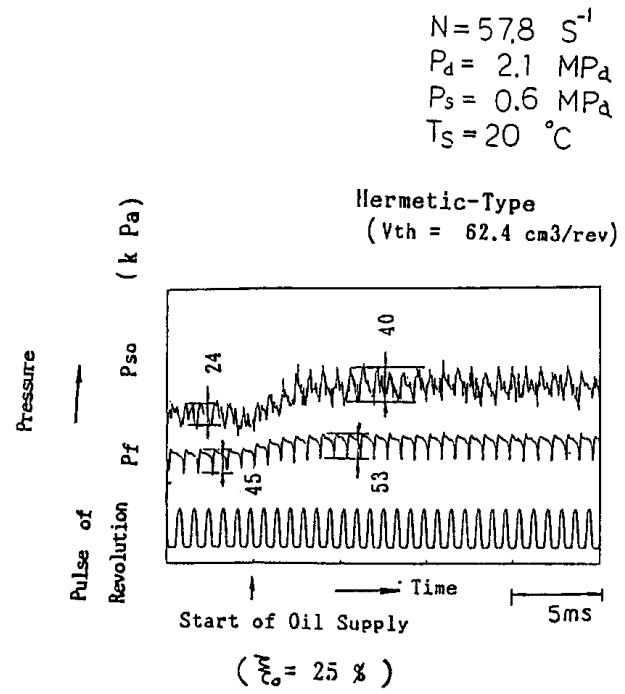

図 11 吸入側油と圧縮機内部の圧力挙動

むね $5 \%$ から $10 \%$ 範囲となる。

（2）油による吐出しガス温度 $T_{d}$ の冷却効果を計
算で求めると, 油含有率 $\xi_{0}$ が $1 \%$ 増加すると $T_{d}$ 值は 約 $1.6^{\circ} \mathrm{C}$ の比率で低下する，この計算結果は実験結果 とおおむね一致していることを確認した。

（3）指圧線図の計測結果から, 油含有率が $5 \%$ よ り小さい領域では油によるシール効果が不十分となる ため, 圧力曲線が断熱圧縮線に対して上に大きくふく らむことがわかった。

（4）循環油加圧動力の計算值は, 圧縮機動力に対 してきん少と見積もられ，この加圧動力は圧縮性能に 大きな影響を及ぼさないと考えられる。

\section{文献}

(1) Tojo, K., ほ 5 名, Proc. Purdue Compre. Technol. Conf., (1986-8), 872.

（2）石井・ほか 5 名，機論, 53-495, C (昭 62), 2295.

(3) 椎林 - ほか 3 名, 空調冷凍講論集（昭 62-4)，121.

（4）日本機械学会編, 機械工学便筧第 9 編（昭 52)，9-28.

（5）森下・ほか 5 名，第 927 回講演会前刷集（昭 58-8）, 9, 日 本機械学会.

（6）森, 潤滑, 13-2 (昭 43), 36. 